\title{
RESEARCH
}

Open Access

\section{Effects of long-term deforestation and remnant forests on rainfall and temperature in the Central Rift Valley of Ethiopia}

Alemayehu Muluneh ${ }^{1,2^{*}}$, Emiel van Loon ${ }^{5}$, Woldeamlak Bewket ${ }^{4}$, Saskia Keesstra ${ }^{1}$, Leo Stroosnijder ${ }^{1}$ and Ashenafi Burka ${ }^{3}$

\begin{abstract}
Background: Some evidence suggests that forests attract rain and that deforestation contributes to changes in rainfall and temperature. The evidence, however, is scant, particularly on smaller spatial scales. The specific objectives of the study were: (i) to evaluate long-term trends in rainfall (1970-2009) and temperature (19812009) and their relationships with change in forest cover, and (ii) to assess the influence of remnant forests and topographical factors on the spatial variability of annual rainfall.

Methods: This study investigated the forest-rainfall relationships in the Central Rift Valley of Ethiopia. The study used 16 long-term (1970-2009) and 15 short-term (2012-2013) rainfall and six long term (1981-2009) temperature datasets. Forest and woodland cover decline over the past 40 years (1970-2009) and the measured distances between the remnant forests and rainfall stations were also used. The long-term trends in rainfall (1970-2009) and temperature (1981-2009) were determined using Mann-Kendall (MK) and Regional Kendall (RK) tests and their relationships with long-term deforestation were evaluated using simple linear regression. Influence of remnant forests and topographical variables on the spatial variability of rainfall were determined by stepwise multiple regression method. A continuous forest and woodland cover decline was estimated using exponential interpolation.

Results: The forest and woodland cover declined from 44\% in 1973 to less than 15\% in 2009 in the Central Rift Valley. Annual rainfall on the valley floor showed an increase by $37.9 \mathrm{~mm} /$ decade while annual rainfall on the escarpments/ highlands decreased by $29.8 \mathrm{~mm} /$ decade. The remnant forests had a significant effect $\left(P\right.$-value $<0.05, R^{2}=0.40$ ) on the spatial variability of the number of rainy days observed over two years (2012-2013), but had little effect on the variability of rainfall distribution. For the total annual rainfall, slope was the best predictor which explained $29 \%$ of the rainfall variability in the Central Rift Valley. For the annual number of rainy days, both slope and elevation explained most of the variability (60\%) of annual number of rainy days.

Conclusion: This study did not find a significant correlation between long-term rainfall trend and forest and woodland cover decline. The rift valley floor warmed significantly due to long-term deforestation in the Central Rift Valley. Topographic factors play a significant role than forest cover in explaining the spatial variability of annual rainfall in the long-term and short term time scale in the Central Rift Valley. But, the short-term rainfall data indicated that the remnant forest had a significant effect on the spatial variability of the number of rainy days.
\end{abstract}

Keywords: Deforestation, Elevation, Forest, Rainfall, Slope, Temperature

\footnotetext{
* Correspondence: muluneh96@yahoo.com

'Wageningen University, Soil Physics and Land Management Group,

Droevendaalsesteeg 4, 6708 Wageningen, PB, Netherlands

${ }^{2}$ Hawassa University, School of Bio-systems and Environmental Engineering,

P.O. Box, 05, Hawassa, Ethiopia

Full list of author information is available at the end of the article
} 


\section{Background}

The loss of vegetation in humid and dry tropical regions is believed to increase the incidence of droughts and floods (Nicholson, 1998) and to also contribute to climate change (e.g. de Sherbinin et al. 2002). For example, a study in Amazon basin suggested that land cover change has the potential to increase the impact of droughts (Bagley et al. 2014). Similarly, Lawrence and Vandecar (2015) indicated that tropical deforestation results in warmer, drier conditions at the local scale. The impacts of changes in land use may contribute more than the greenhouse effect to regional climate change, occurrence of droughts, and desertification (e.g. Savenije 1996). Forest protection and re-vegetation can mitigate drought and flood risks. The protection of tropical forests in Madagascar and Indonesia, for example, has benefited drought and flood mitigation (Kramer et al. 1997; Pattanayak and Kramer 2001). Makarieva et al. (2009) suggested the potential for forest-mediated solutions to the problems of global desertification and water security. The need for improving our understanding of the role of vegetative cover in climate is thus becoming more urgent due to the increasing magnitude of change that humans are imposing on vegetation (Sanderson et al. 2012). Several studies have already advocated for a more comprehensive assessment of the net climate effect of land cover change policies on climate, beyond the global warming potential (e.g. Castillo and Gurney 2013, Davies-Barnard et al. 2014, Bright et al. 2015).

In recent years, there has been an increasing amount of literature on the consequence of deforestation on the regional and global scales (Hanif et al. 2016). The long term effect of deforestation in the Amazonian climate showed $60 \%$ reduction in the rainfall (Nobre et al. 2009). Similarly, the deforestation in 2010 over the Amazonian basin showed up to $1.8 \%$ reduction in rainfall (Lawrence and Chase 2010). Additionally, modeling studies over the Asian region suggested that a large-scale deforestation can lead to reduced precipitation (Dallmeyer and Claussen 2011). For example, Cao et al. (2015) found that land use/land cover in Northern China has altered the regional climate over the past decade (between 2001 and 2010). Another study in Congo Basin, Africa has revealed that decreased evapotranspiration due to deforestation can reduce the rainfall up to $50 \%$ over the entire basin (Nogherotto et al. 2013). A global transect study by Makarieva et al. (2009) also found that precipitation increased inland for several thousand kilometres in forested regions such as the Amazon and Congo River basins whereas precipitation declined exponentially with distance from the ocean in non-forested regions. Such studies on regional/global/continental scales do not clearly show how forests affect rainfall on smaller scales, from a few to about one hundred kilometres in diameter.
Because, the net local/regional impacts of forest cover/ deforestation are dependent on the type and scale of land cover change and on local conditions (Pitman and Lorenz 2016, Lucia et al. 2017). Meso- and local-scale observational studies have also produced contradicting results. Some deforestation experiments suggest reduced precipitation (e.g. Lejeune et al., 2015, Badger and Dirmeyer 2016) while others suggest increases (e.g. Dirmeyer and Shukla 1994, Bonan 2008).

The role of deforestation in temperature change also has two competing effects: warming due to the reduction in evapotranspiration and cooling due to the increase in surface albedo. The albedo-induced decrease of temperature following deforestation can be locally offset by the warming effect due to a decrease of latent heat flux, with a resulting net warming effect of the surface, along with a decrease of precipitation (Spracklen and Garcia-Carreras 2015, Lawrence and Vandecar 2015). Tropical deforestation studies using climate models almost always simulate warming and drying (Badger and Dirmeyer 2016). Most recently Lucia et al. (2017) from synthesizes results of published modelling and observational studies focusing on changes in surface air temperature and precipitation due to biophysical effects of land cover change reported models indicate that large scale (extreme) land cover changes have a strong regional effect on temperature and precipitation while observational studies also find significant local/regional temperature effects of land cover change.

Small-scale spatial variability of rainfall could also be caused by various topographical parameters such as elevation, slope, and slope aspect (Agnew and Palutikof 2000; Marquínez et al. 2003). Rainfall often increases with elevation due to the orographic effect. Slope and slope aspect influence near-surface temperatures and water availability due to varying exposure to solar radiation and wind (Barry 1992; Bolstad et al. 1998). Such studies focus only on topographic factors without due consideration of vegetation cover and water bodies. Water bodies also commonly affect rainfall distribution by influencing local meteorological conditions (e.g. Ba and Nicholson 1998).

The studies reviewed here at best indicate that no scientific consensus exists on the meso- and local scales impacts of forest cover and deforestation on climate and remains a subject of ongoing research, indicating the need for region-specific empirical data and further research. The natural high forests of Ethiopia which were estimated to have once covered $40 \%$ of the country, declined to only $13.7 \%$ in the 1990 's and to $11.5 \%$ in 2010 (FAO 2010). Today, Ethiopian forests disappear at a rate of $1.1 \%(140,000 \mathrm{ha})$ per year (FAO 2010). Thus, continuous deforestation in Ethiopia makes such a study crucial. The Central Rift Valley is, among other 
Ethiopian areas, affected by a continuous forest and woodland decline.

Thus, our hypothesis is that long term deforestation causes rainfall and temperature pattern change and even small scale remnant forests have a beneficial effect of rainfall and one of the recommended impact reducing strategies, therefore, is the protection and plantation of small forests. To test our hypothesis this study was conducted in two ways: First, the effect of existing remnant forests on rainfall at the landscape scale was studied by installing automatic rain gages in forests and open areas following a transect line. Second, long term relationship between the long term deforestation and rainfall and temperature pattern change was studied to determine the effect of deforestation on climate. The specific objectives of the study were: (i) to evaluate long-term rainfall (1970-2009) and temperature (1981-2009) trend and their relationships with long term forest and woodland decline(deforestation) and (ii) to assess the influence of remnant forests and topographical factors on the spatial variability of long-term (1970-2009) and short-term (2012-2013) annual rainfall and number of rain days.

\section{Methods}

\section{The study area}

The Central Rift Valley covers an area of about $13,000 \mathrm{~km}^{2}$ at approximately $38^{\circ} 00^{\prime}-39^{\circ} 30^{\prime} \mathrm{E}, 7^{\circ} 00^{\prime}-8^{\circ} 30^{\prime}$ $\mathrm{N}$ (Fig. 1). It is a sub-basin of the Rift Valley Lakes Basin and is part of the Great East African Rift Valley, which covers the major dryland portion of the country, and has three landscape units (physiographic regions): the valley floor, escarpments, and highlands. The altitude is $1600 \mathrm{~m}$ above mean sea level (a.s.l) around the rift lakes and ranges from about 2000 to $3200 \mathrm{~m}$ a.s.l in the eastern and western highlands.

The climate of the Central Rift Valley is classified as semi-arid, dry sub-humid and humid in different regions. Based on the Central Rift Valley climate data analysis (1970-2009) mean annual rainfall and mean annual temperature range from 737 to $955 \mathrm{~mm}$ and 17 to $20{ }^{\circ} \mathrm{C}$, respectively (Muluneh et al. 2017). The region has three main seasons. A long rainy season (Kiremt) extends between June and September and represents $50-70 \%$ of the total annual rainfall. Kiremt rainfall is mostly controlled by the seasonal migration of the inter-tropical convergence zone (ITCZ). A dry period extends between October and February, with occasional rains that account for about $10-20 \%$ of the total annual rainfall. The dry period occurs when the ITCZ lies south of Ethiopia, during which time the north-easterly trade winds traversing Arabia dominate the region (Muchane 1996). A short rainy season (Belg) occurs during March to May, with $20-30 \%$ of the total annual rainfall. The Belg rainfall is caused by humid easterly and south-easterly winds from the Indian Ocean (Seleshi \& Zanke 2004).The intense heating of the high plateau causes the convergence of the wet monsoonal currents from the southern Indian and Atlantic Oceans, bringing rain to the region (Griffiths 1972). The pattern of rainfall on the valley floor is mostly from relatively intense (up to $100 \mathrm{~mm} / \mathrm{h}$ ) storms compared to the highlands with highest intensities only up to $70 \mathrm{~mm} / \mathrm{h}$ (Makin et al. 1975).

The soils of the Central Rift Valley are mainly derived from young volcanic rocks, with textures ranging from sandy loam to clay loam with varying levels of fertility and degradation.

The distribution of plants in the study area is highly influenced by elevation, which also dictates the rainfall pattern (Musein 2006). The floor of the valley is largely dominated by deciduous acacia woodland and wooded grassland that are increasingly becoming more open (Feoli and Zerihun 2000), whereas deciduous woodlands (Olea europaea, Celtis, Dodonaea viscosa, and Euclea) occupy the escarpments (Mohammed and Bonnefille 1991). Montane forests dominated by Podocarpus gracilior grow between 2000 and $3000 \mathrm{~m}$ a.s.l on the eastern plateaus bordering the rift (Abate 2004).

Land-cover change in the Central Rift Valley commenced before the 1970s (Makin et al. 1975), but a significant amount of forest cover lost between the 1970s and the early 1990s due to increasing pressure from the growing population and an unstable political system (Seifu 1998, Bekele 2003). Increasing and progressive settlement since the 1970s has replaced rangelands around the lakes and the montane forests on the escarpments and plateaus with small- to medium-scale farms, some of which are mechanised (Woldu and Tadesse 1990, Kindu et al. 2013). In the Central Rift Valley, woodlands, forested areas and water bodies decreased by 69, 66 and 15\% respectively, between 1973 and 2006, mainly due to their conversion to agricultural land (Meshesha et al. 2012) (Fig. 2).

The Munessa-Shashemene forest, a conspicuous remnant of the once dense dry tropical Afromontane vegetation, is considered as remnant forest for this study as well. It is located on the south-eastern escarpment of the Central Rift Valley (Fig. 1) and is comprised of natural woody vegetation such as podocarps, junipers, and forest plantations dominated by a few exotic species such as eucalyptus, cypresses, and pines. The forest is now designated as a High Priority Forest Area protected by the government. The Munessa-Shashemene forest has been increasingly deforested for a long time, a process that is still ongoing mainly due to commercial logging and agricultural expansion (Seifu 1998, Kindu et al. 2013). The natural forest cover declined from $21,723.3$ ha in 1973 to 9588 ha in 2012, a loss of nearly $56 \%$ in four decades (Kindu et al. 2013). The woodland 


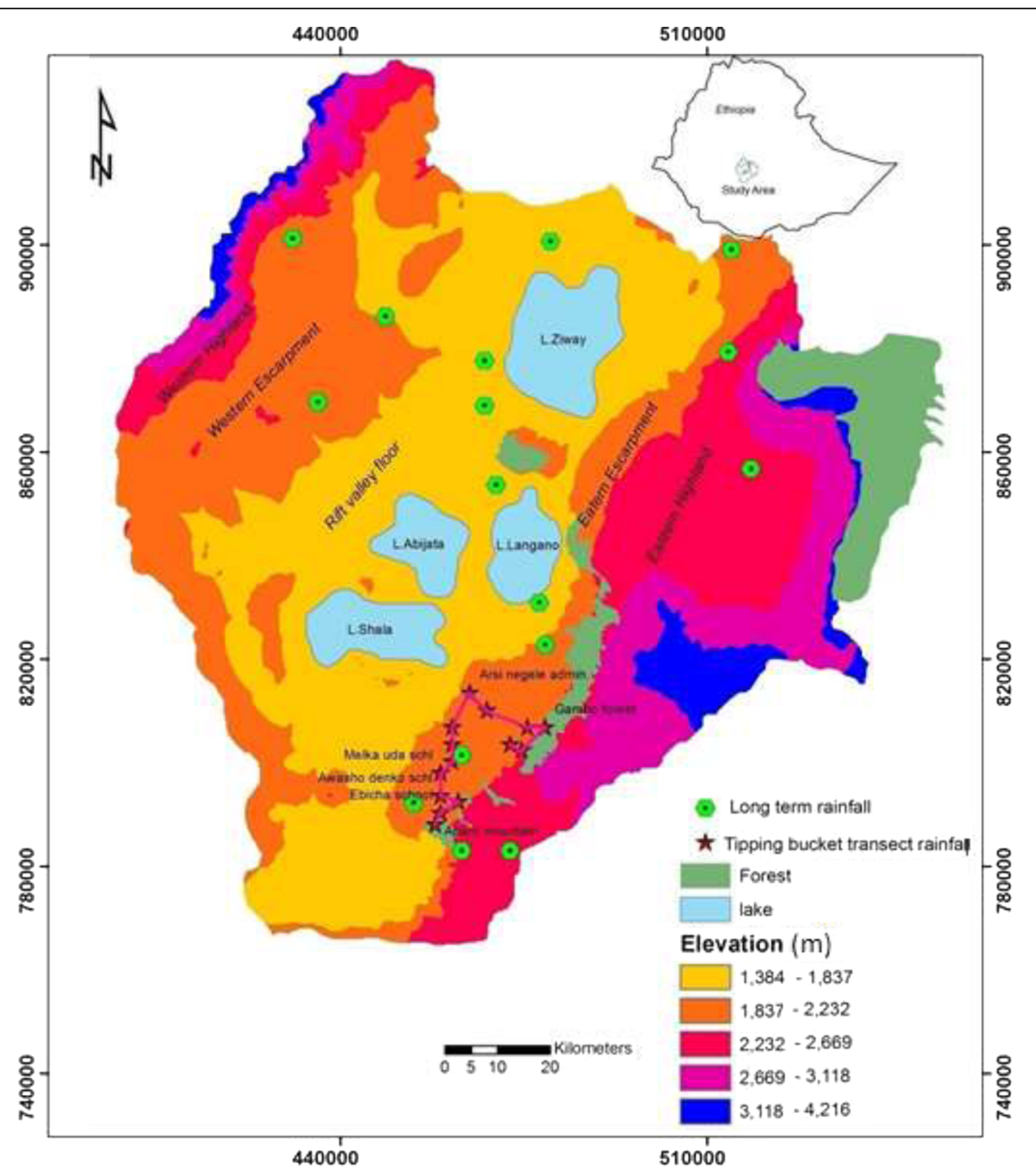

Fig. 1 Location of the study area and the meteorological stations, lakes, and remnant forests in the Central Rift Valley of Ethiopia

area around Munessa-Shashemene forest has also significantly decreased. Only 650.6 ha (5.4\%) of $11,832.4$ ha of woodlands in 1973 remained unchanged in 2012 (Kindu et al. 2013).

The Central Rift Valley encompasses the four major lakes Ziway, Abiyata, Langano, and Shala with areas of $440,180,230$, and $370 \mathrm{~km}^{2}$, respectively (Ayenew 2003), i.e. the lakes together occupy an area of about $1220 \mathrm{~km}^{2}$ on the floor of the valley (Fig. 1). Also it consists of streams and wetlands with unique hydrological and ecological characteristics. For example, Lake Ziway receives most of its water from two tributaries (Meki and Ketar Rivers) of the western and eastern escarpments. Lake Ziway is connected with Lake Abiyata through Bulbula River. Lake Langano is mainly maintained by five major rivers (Huluka, Lepis, Gedemso, Kersa and Jirma rivers) and it is connected with Lake Abiyata through Horakelo River. The surface inflows to Lake Shala come from two main sources (Dadaba and Gidu Rivers) enters from the southeastern and western escarpments.

\section{Data collection \\ Rainfall and temperature data}

Two sets of rainfall data were used. (i) Long-term (1970-2009) daily rainfall data were collected at 16 meteorological stations (five on the valley floor and 11 in the escarpments/highlands) by the National Meteorological Agency of Ethiopia (Table 1). (ii) Short-term (2012-2013) rainfall data were directly collected from a network of 15 watchdog tipping bucket rain gauges systematically installed along transects of approximately $60 \mathrm{~km}$ traversing both forested and open areas (Fig. 1). The distance between neighbouring rain gauges was $<5 \mathrm{~km}$, as suggested by Hubbard (1994) for explaining at least $90 \%$ of the variation between sites. Increasing the density of the monitoring network can also improve the 

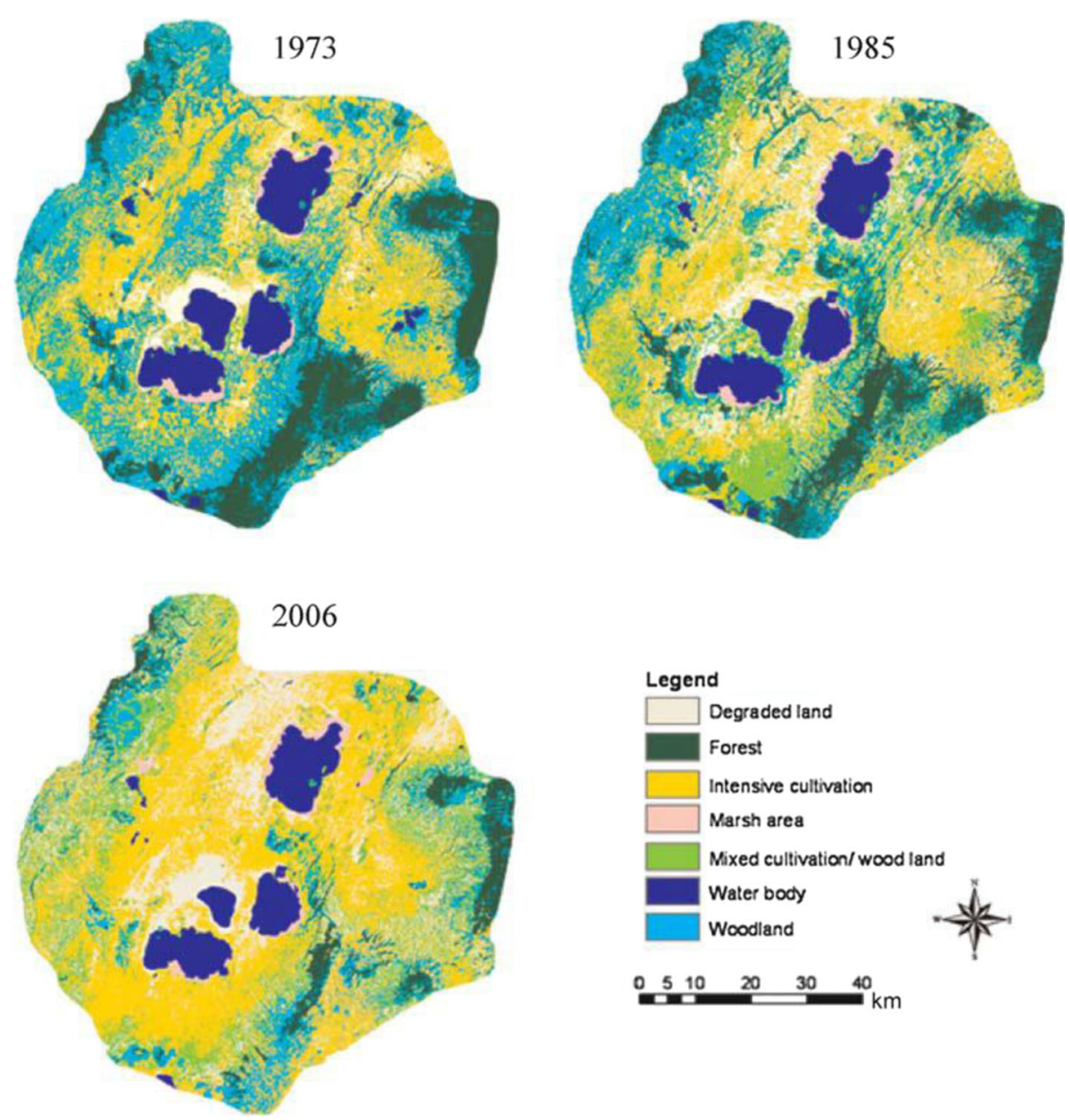

Fig. 2 Changes in land use and cover in the Central Rift Valley, 1973-2006 (adapted from Meshesha et al. 2012)

quality of spatial rainfall estimation. Rainfall and the number of rainy days were the two important variables used for the subsequent analysis.

The temperature trend in the region were analysed using data for the maximum and minimum temperatures from the six meteorological stations from which quality temperature data were obtained for 1981-2009 (Table 2).

\section{Forest data}

Two types of forest data were used. (i) The long-term changes in forest and woodland cover were required to assess the effect of deforestation on rainfall patterns. A continuous decline in forest and woodland cover, described as the annual percentage of remaining forest and woodland area for 40 years (1970-2009), was determined using exponential interpolation based on measurements of existing forest and woodland cover from an analysis of remotely sensed data for 1973, 1985 and 2006 (Landsat multiresolution and multispectral data for 1973 and Landsat thematic mapping for 1985 and 2006 were used to classify Land use and cover) (Fig. 2) (Meshesha et al. 2012). This type of interpolation has been used previously by Gebrehiwot et al. (2010). (ii) The distances between the remnant forests and each of the rainfall stations were used as independent variables to assess the influence of the remnant forests on rainfall distribution. Euclidean distances were computed to determine the distance of each rain gauge from the forest.

\section{Topographical variables (elevation, slope, and slope aspect)} Data for elevation, slope, and slope aspect were collected at each of the meteorological stations. These topographic variables represent the explanatory variables in our analysis. The mean values of the topographical variables within a radius of $2 \mathrm{~km}$ were used rather than only the value at the station to normalize local effects (Daly et al. 1994). Large-scale topographical features at a resolution of 2-15 km yield a high correlation with precipitation (Daly et al. 1994). Aspect is a circular variable, so the vector was decomposed into two orthogonal components: sin (aspect) and cos (aspect). Sin (aspect) yields a 
Table 1 Characteristics of the meteorological stations used in the study

\begin{tabular}{|c|c|c|c|c|c|c|c|c|c|}
\hline \multicolumn{10}{|c|}{ 40-year rainfall data (1970-2009) } \\
\hline Landscape unit & Meteorological Station & $\begin{array}{l}\text { Northing } \\
\text { (m) }\end{array}$ & $\begin{array}{l}\text { Easting } \\
\text { (m) }\end{array}$ & $\begin{array}{l}\text { Elevation } \\
\text { (m) }\end{array}$ & $\begin{array}{l}\text { Slope } \\
\text { (degree) }\end{array}$ & $\begin{array}{l}\text { Sin } \\
\text { (aspect) }\end{array}$ & $\begin{array}{l}\text { Cos } \\
\text { (aspect) }\end{array}$ & $\begin{array}{l}\text { Distance to } \\
\text { forest }(\mathrm{km})\end{array}$ & Period \\
\hline \multirow[t]{5}{*}{ Rift valley floor } & Langano & 477,935 & 830,871 & 1600 & 3.3 & 0.17 & 0.98 & 2 & $1981-2009$ \\
\hline & Bulbula & 469,732 & 853,566 & 1610 & 1.03 & -0.70 & -0.70 & 23 & 1970-2009 \\
\hline & Adami Tulu & 467,545 & 868,876 & 1636 & 1.6 & 0.70 & -0.70 & 27 & 1970-2009 \\
\hline & Ziway & 467,545 & 877,624 & 1640 & 2.0 & 1 & 0 & 31 & $1981-2009$ \\
\hline & Meki & 480,121 & 900,589 & 1664 & 1.03 & 0 & -1 & 44 & 1970-2009 \\
\hline \multirow[t]{12}{*}{ Escarpments/highlands } & Wondo Genet & 463,190 & 782,974 & 1880 & 6.25 & -0.92 & -0.39 & 6 & 1970-2009 \\
\hline & Koshe & 448,575 & 886,170 & 1910 & 1.7 & 0.17 & 0.98 & 31 & 1970-2009 \\
\hline & Kuyera & 806,928 & 461,367 & 1932 & 1.72 & -1 & 0 & 13.5 & 1970-2009 \\
\hline & Shashemene & 453,994 & 792,195 & 1933 & 1.03 & -0.64 & 0.76 & 19 & 1970-2009 \\
\hline & Tora & 435,696 & 869,603 & 1998 & 1.0 & -1 & 0 & 35 & 1970-2009 \\
\hline & Butajira & 430,910 & 901,136 & 2000 & 2.5 & 0.37 & -0.92 & 55 & 1970-2009 \\
\hline & Degaga & 479,097 & 822,688 & 2076 & 3.3 & -0.64 & 0.76 & 4 & 1970-2009 \\
\hline & Kulumsa & 514,688 & 899,040 & 2202 & 4.5 & -0.70 & -0.70 & 18 & 1970-2009 \\
\hline & Assela & 514,021 & 879,265 & 2390 & 4.7 & -1 & 0 & 6 & 1970-2009 \\
\hline & Sagure & 518,378 & 856,664 & 2480 & 2.0 & -0.70 & -0.70 & 18 & 1970-2009 \\
\hline & Kofele & 472,392 & 782,968 & 2620 & 1.7 & -1 & 0 & 8 & 1970-2009 \\
\hline & \multicolumn{9}{|c|}{ Two-year rainfall data (2012-2013) } \\
\hline \multirow[t]{15}{*}{ Escarpments/highlands } & Abaro mount & 458,040 & 788,137 & 2325 & 8.5 & -0.93 & 0.38 & 0.01 & 2012-2013 \\
\hline & Gambo forest & 479,028 & 806,917 & 2187 & 5.0 & -0.93 & 0.38 & 0.3 & $2012-2013$ \\
\hline & Reji schl & 474,611 & 802,498 & 2176 & 4.5 & -0.93 & 0.38 & 0.4 & 2012-2013 \\
\hline & Sole forest & 462,460 & 792,556 & 2153 & 2.5 & -0.93 & 0.38 & 0.1 & $2012-2013$ \\
\hline & Asheka leps & 475,717 & 806,919 & 2145 & 1.7 & -0.93 & 0.38 & 2.5 & $2012-2013$ \\
\hline & Kalo & 472,403 & 803,604 & 2138 & 1.7 & -0.93 & 0.38 & 2.8 & $2012-2013$ \\
\hline & Ebicha & 459,146 & 790,347 & 2127 & 2.5 & -1 & 0 & 1 & 2012-2013 \\
\hline & Awasho & 459,149 & 793,664 & 2035 & 2.5 & 0.17 & 0.98 & 2 & $2012-2013$ \\
\hline & Seyo meja & 467,992 & 810,240 & 2035 & 1.7 & 0.7 & 0.7 & 11 & 2012-2013 \\
\hline & Melka uda & 459,152 & 798,086 & 1977 & 0.86 & -0.93 & 0.38 & 7.5 & 2012-2013 \\
\hline & Kerara fana & 461,362 & 800,295 & 1973 & 1.7 & -0.93 & 0.38 & 6.5 & $2012-2013$ \\
\hline & Augeta ilala & 461,365 & 803,612 & 1972 & 0.86 & -1 & 0 & 13.5 & $2012-2013$ \\
\hline & Arsi Negele & 464,683 & 813,559 & 1941 & 2.5 & -0.93 & 0.38 & 15 & $2012-2013$ \\
\hline & Shashemene & 792,195 & 453,994 & 1933 & 1.03 & -1 & 0 & 4 & 2012-2013 \\
\hline & Kuyera & 461,367 & 806,928 & 1932 & 1.72 & -0.64 & 0.76 & 14.5 & $2012-2013$ \\
\hline
\end{tabular}

measure of east/west exposure (+1 represents due east, -1 represents due west), and cos (aspect) yields a north/ south exposure ( +1 represents due north, -1 represents due south) (Hession and Moore 2011).

\section{Data analysis}

\section{Long-term trends of rainfall and temperature}

A long-term rainfall data set was used (i) to assess the long-term rainfall and temperature trend in the Central Rift Valley and comparing it to forest and woodland cover decline, ii) The long-term rainfall data were also used as dependent variables for analysing the effect of forest cover on local rainfall distribution.

The effects of forest and woodland cover decline (deforestation) on rainfall distribution were assessed by the following two approaches (Gadgil 1978; Meher-Homji 1980). (i) The rainfall pattern at the same station over a long period were analysed during which deforestation occurred. (ii) Rainfalls between areas were compared within the same climatic type, one area forested and the other without natural vegetation. The annual rainfall trends were spatially distinct between the valley floor 
Table 2 The six meteorological stations with temperature data set (maximum \& minimum temperature) used in the study

\begin{tabular}{llllll}
\hline 29-year Temperature data (1981-2009) & & & \\
\hline Landscape unit & Meteorological Station & Northing $(\mathrm{m})$ & Easting $(\mathrm{m})$ & Elevation $(\mathrm{m})$ & Period \\
Rift Valley Floor & Ziway & 467,545 & 877,624 & 1640 & $1981-2009$ \\
& Langano & 477,935 & 830,871 & 1600 & $1981-2009$ \\
& Adami Tulu & 467,545 & 868,876 & 1636 & $1981-2009$ \\
Escarpments/highlands & Assela & 514,021 & 879,265 & 2390 & $1981-2009$ \\
& Kulumsa & 514,688 & 899,040 & 2202 & $1981-2009$ \\
& Butajira & 430,910 & 901,136 & 2000 & $1981-2009$ \\
\hline
\end{tabular}

and the adjoining highlands (Muluneh et al. 2017), so the relationship between forest depletion and rainfall pattern were determined separately for the valley floor and the escarpments/highlands.

The long-term temperature trend were analysed by categorising the meteorological stations with temperature data in their respective landscape units: valley floor and escarpments/highlands. Based on this categorisation, each landscape unit had three meteorological stations with temperature data for the trend analysis.

The trends of rainfall and temperature at station and regional levels were investigated using Mann-Kendall (MK) and Regional Kendall (RK) tests, respectively (Helsel and Frans 2006). MK tests have been used with Sen's Slope Estimator for the determination of trend magnitude. The MK test is especially suitable for nonnormally distributed data, data containing outliers, and non-linear trends (Helsel and Hirsch 2002). The RK test is applicable to data from numerous locations, and one overall test can determine whether the same trend is evident across those locations (Helsel and Frans 2006). The station-level trend for rainfall was not analysed, because this analysis for most of the stations in this study has been published in the previous study (Muluneh et al. 2017).

\section{Effect of deforestation on rainfall and temperature}

A simple linear regression was used to determine the relationships between deforestation (described as percentage of remaining forest and woodland cover each year) and annual rainfall and number of rainy days. Similarly, the effect of deforestation on temperature was determined using linear regression model during the period of available temperature data (1981-2009).

\section{Influence of remnant forests and topographical variables on the spatial variability of rainfall}

Stepwise multiple regression was used for selecting significant predictive variables. Annual rainfall and number of rainy days as dependent variables and distances from forests, elevation, slope, and slope aspect as explanatory variables were used. These topographic data and geographic features were derived from Landsat
Thematic Mapper (TM) satellite image (Data available from the U.S. Geological Survey) using UTM-WGS 1984-ZONE $37 \mathrm{~N}$ map projection. The slope is derived from ASTER global digital elevation model (GDEM, 2011) with a pixel size of $30 \mathrm{~m}$ (available at https://aster web.jpl.nasa.gov/gdem.asp).

Sixteen rainfall datasets were used for the multiple regression. Distance to lakes was another predictor, but it was not included in the analysis because the stations on the valley floor were in similar proximities to the lakes, but the stations in the escarpments/highlands were in different climatic zones, and most stations in the highlands were far from the range of lake penetration distances of 15-45 km (e.g. Estoque et al. 1976; Ryznar and Touma 1981).

The multiple regression equations have the form:

$$
\mathrm{Y}=\alpha+\beta_{1} X_{1}+\beta_{2} X_{2}+\ldots+\beta_{p} X_{p}
$$

where Y (the dependent variable) is the annual rainfall and number of rainy days,

$X$ is a selected subset of $\mathrm{p}$ explanatory variables, $\beta$ is the slope of each explanatory variable, and $\alpha$ is the intercept. The confidence interval for multiple linear regression is $95 \%$.

Many studies have used stepwise regression to examine the relationship between rainfall and topographical variables (Agnew and Palutikof 2000; Marquínez et al. 2003; Oettli and Camberlin, 2005; Moliba Bankanza 2013). The method applied here began by identifying the 'best' explanatory variable and incorporating it into the model and then iteratively identifying the next 'best' predictor until the model could no longer be improved. Two criteria were used to select the 'best' explanatory variables: statistical significance (at $P<0.05$ ) and the tolerance criterion for evaluating the underlying assumption of independence between explanatory variables. If two variables were significantly alike, their contribution to the variance in the dependent variable becomes impossible to determine. The problem primarily occurs when predictor variables are more strongly 
correlated with each other than with the response variable.

The tolerance of a variable $\mathrm{X}_{\mathrm{j}}, \mathrm{Tol}_{j}$, with the other variables is defined as:

$$
\mathrm{Tol}_{j}=1-R_{j}^{2}
$$

where $R_{j}$ is the multiple correlation coefficient between variables $X_{j}$ and $X_{1}, X_{j-1}, X_{j}+1 \ldots, X_{n}$. If the tolerance is close to 0 , the variable $X_{j}$ is a linear combination of the others and is removed from the equation, and tolerances close to 1 indicate independence. Tolerances and $P$ values were calculated for each independent variable at each step in the process. Independent variables with associated tolerances $\geq 0.1$ and $P$-values $\leq 0.05$ were entered stepwise into the model.

\section{Results}

Rainfall and temperature trends

Rainfall trends

The Regional Kendall test indicated that the general trend of annual rainfall and number of rainy days tended to increase significantly on the valley floor and to decrease significantly in the escarpments/highlands (Table 3). The decadal increase in rainfall on the valley floor was approximately $38 \mathrm{~mm}$, and the decrease in the escarpments/highlands was approximately $29 \mathrm{~mm}$. Annual rainfall for the entire region decreased significantly, and the number of rainy days tended to decrease, although not significantly (Table 3).

The time-series analysis showed similar trends of increasing annual rainfall on the valley floor and decreasing annual rainfall and number of rainy days in the escarpments/highlands (Fig. 3).

\section{Temperature trends}

Table 4 presents the trends of mean annual maximum and minimum temperatures for 1981-2009. The mean maximum temperature increased significantly at all three stations on the valley floor that recorded temperatures (Ziway, Langano, and Adami Tulu). All three stations recorded an increasing tendency in mean minimum temperature, but the increase was statistically significant at only one station (Langano). A significant increase in maximum temperature was recorded in the escarpments/highlands only at the Butajira station. The maximum temperature increased significantly both on the valley floor landscape unit and in the escarpments/ highlands landscape units.

The mean minimum temperature decreased significantly at two of the three highland stations (Kulumsa and Butajira). The minimum temperature increased significantly on the valley floor landscape unit but not significantly in the escarpments/highlands units.

The mean maximum temperature in the Central Rift Valley increased by $0.4{ }^{\circ} \mathrm{C} /$ decade during $1981-2009$, but the mean minimum temperature remained relatively stable.

\section{Deforestation (Forest and woodland decline)}

Figure 4 shows Percentage forest and woodland cover decline over time after exponential interpolation between three different years of forest and woodland cover data points obtained from satellite images. Based on three periods of deforestation data points from satellite images (1973, 1985 and 2006) and subsequent interpolation, the forest and woodland cover declined from $44 \%$ in 1973 to less than 15\% in 2009 (Fig. 4).

\section{Effect of deforestation on long-term rainfall pattern}

Figure 5 shows the linear relationship between forest and woodland cover decline and (a) annual rainfall and (b) number of rainy days over 40 years across the Ethiopian Central Rift Valley. The continuous decline of forest and woodland cover for four decades was weakly correlated with mean annual rainfall and number of rainy days across the 16 stations in the Central Rift Valley. However, despite their weak correlation, both annual rainfall and number of rainy days showed consistent decrease during the period of forest and woodland cover decline. But, forest and woodland decline looks better correlated with decreasing mean number of rainy days than mean annual rainfall (Fig. 5).

\section{Effect of deforestation on temperature}

Figure 6 presents the linear relationship between forest and woodland cover decline and maximum and minimum temperatures in the rift valley floor and escarpments/highlands for about three decades (1981-2009). The result showed that the increase in the maximum daily temperature in the rift valley floor was well

Table 3 Trends in annual rainfall and number of rainy days for the rift valley floor and escarpments/highlands

\begin{tabular}{llll}
\hline Stations & $\begin{array}{l}\text { Change in annual } \\
\text { rainfall (mm/decade) }\end{array}$ & $\begin{array}{c}P \\
\text { Change in number of } \\
\text { rainy days (days/decade) }\end{array}$ & $\begin{array}{l}P .1 \\
\text { Rift valley floor (5 stations) }\end{array}$ \\
$\begin{array}{lll}\text { Escarpments/highlands (11 stations) } \\
\text { Central Rift Valley (valley floor }+\end{array}$ & -29.8 & $0.0014^{*}$ & -1.6 \\
escarpments/highlands) (16 stations) & -12.5 & $0.000^{*}$ & -0.19 \\
\hline
\end{tabular}

*Significant at $P<0.05(95 \%$ confidence interval) 


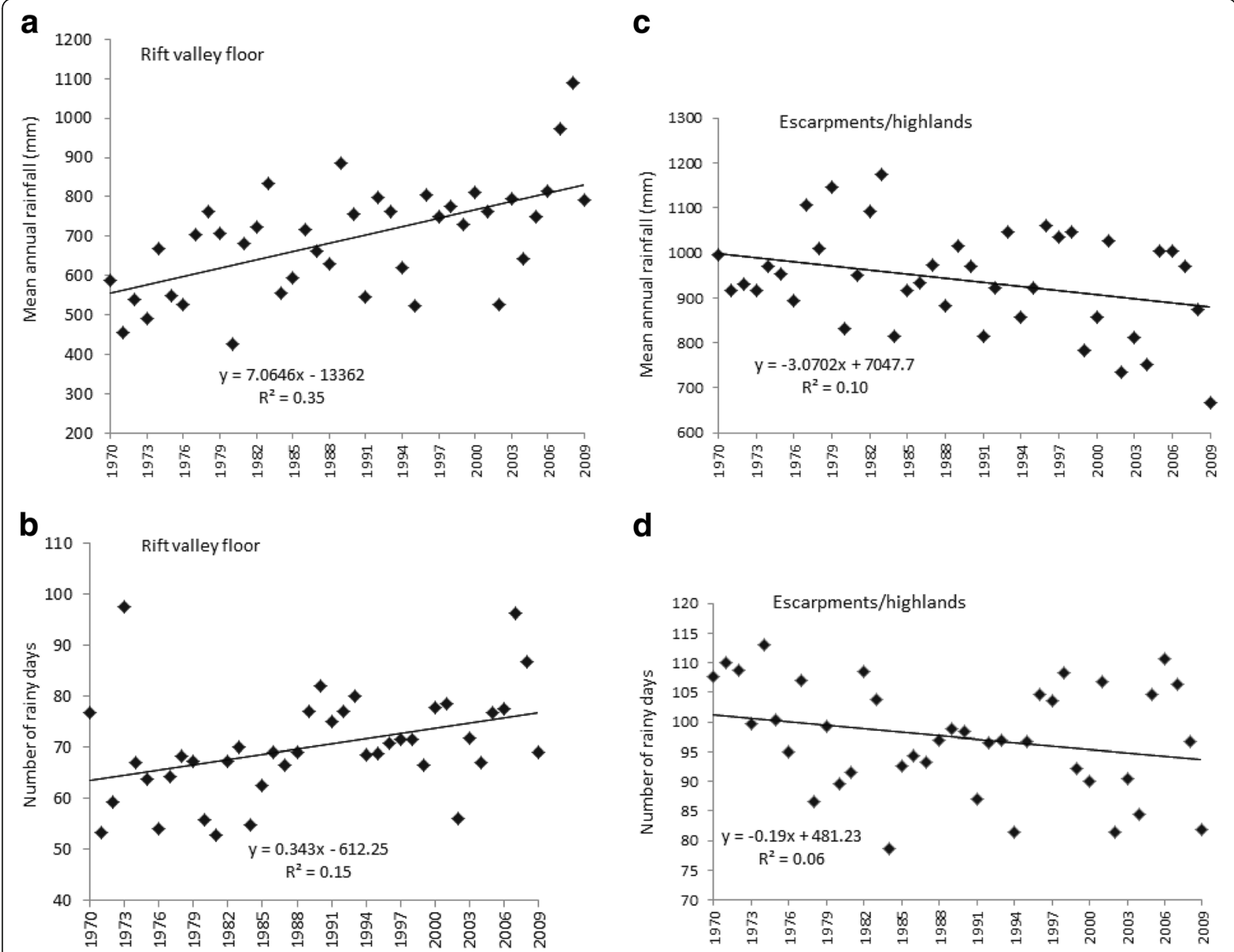

Fig. $\mathbf{3}$ Time series analysis of $(\mathbf{a}, \mathbf{c})$ annual rainfall and $(\mathbf{b}, \mathbf{d})$ number of rainy days for $(\mathbf{a}, \mathbf{b})$ the rift valley floor and $(\mathbf{c}, \mathbf{d})$ escarpments/highlands using simple linear regression from the mean of five stations on the valley floor and 11 stations in the escarpments/highlands. The lines indicate the linear fitting of the series for 1970-2009

Table 4 Trends in annual maximum and minimum temperatures on the rift valley floor and in the escarpments/highlands

\begin{tabular}{|c|c|c|c|c|c|}
\hline \multirow[t]{2}{*}{ Landscape unit } & \multirow{2}{*}{$\begin{array}{l}\text { Meteorological } \\
\text { Station }\end{array}$} & \multicolumn{2}{|l|}{ Tmax } & \multicolumn{2}{|l|}{ Tmin } \\
\hline & & Trend $\left({ }^{\circ} \mathrm{C} /\right.$ decade $)$ & $P$ & Trend $\left({ }^{\circ} \mathrm{C} /\right.$ decade $)$ & $P$ \\
\hline \multirow[t]{3}{*}{ Escarpments/highlands } & Assela & 0.33 & 0.216 & 0.34 & 0.095 \\
\hline & Kulumsa & 0.00 & 1.000 & -0.52 & $0.032^{*}$ \\
\hline & Butajira & 0.20 & $0.013^{*}$ & -1.25 & $0.004^{*}$ \\
\hline Unit & & 0.19 & $0.0307^{*}$ & -0.4 & 0.0523 \\
\hline \multirow[t]{3}{*}{ Valley floor } & Ziway & 0.44 & $0.000^{*}$ & 0.22 & 0.275 \\
\hline & Langano & 1.20 & $0.001^{*}$ & 1.00 & $0.011^{*}$ \\
\hline & Adami Tulu & 0.56 & $0.000^{*}$ & 0.03 & 0.866 \\
\hline Unit & & 0.63 & $0.0000^{*}$ & 0.2 & $0.0447^{*}$ \\
\hline Central Rift Valley & & 0.4 & $0.000^{*}$ & 0.00 & 0.96 \\
\hline
\end{tabular}




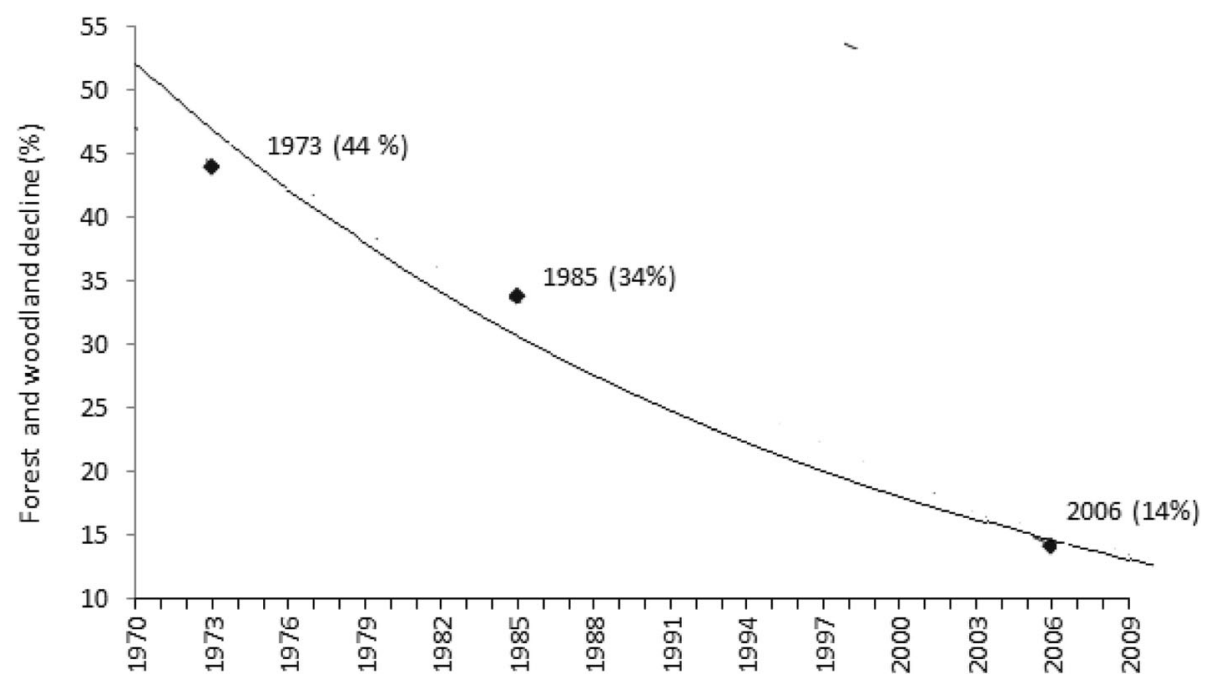

Fig. 4 Percentage forest and woodland decline over time (curved line) after exponential interpolation between three forest and woodland cover data points obtained from satellite images (percentage forest and wood land decline at three respective periods: 1973(44\%), 1985 (34\%) \& 2006 (14\%))

correlated with forest and woodland cover decline $\left(R^{2}=0.62\right)$, whereas the maximum daily temperature in the escarpments/highlands was poorly correlated with forest and woodland cover decline $\left(R^{2}=0.14\right)$. However, the linear relationship between forest and woodland cover decline and the minimum daily temperature was poorly correlated both in the rift valley floor and escarpments/highlands.

\section{The influence of forests and topographical variables on spatial rainfall distribution Long-term rainfall (1970-2009)}

For the total annual rainfall, slope was the best predictor which explained $29 \%$ of the rainfall variability in the Central Rift Valley (Table 5). However, for the annual number of rainy days, both slope and elevation explained most $(60 \%)$ of the variability in the multiple regression model (Table 5). Elevation was not a significant factor for the spatial variability of total annual rainfall in the Central Rift Valley.

\section{Short-term rainfall (2012-2013)}

For a better understanding of the effect of remnant forests on local rainfall distribution, 15 tipping bucket rain gauges were installed systematically along a transect to the forest where the rainfall data were collected for two subsequent years. All gauges were in the same climatic zone (sub-humid) as that of the remnant forest. The annual rainfall and number of rainy days from the shortterm data were explained by elevation and distance from the remnant forest $\left(R^{2}\right.$ of 0.26 and 0.40 , respectively, Table 5). Distance from the forest was not significantly correlated with total annual rainfall, but both total annual rainfall and number of rainy days were negatively correlated with distance from the forest (Fig. 7), indicating that both total annual rainfall and number of rainy days increased closer to the forest.

\section{Discussion \\ Rainfall and temperature trends Rainfall trends}

The previous analysis of the station-level rainfall trend (Muluneh et al. 2017) was consistent with our analysis of the regional trend where stations on the valley floor showed an increasing trend and stations in the escarpments/highlands showed a decreasing trend. The increased temperature due to high deforestation and a presence of a chain of lakes in the rift valley floor could also attribute for increased rainfall in the rift valley floor.

\section{Temperature trends}

The warming trend indicated in this study is consistent with previous studies that reported a warming trend in the Central Rift Valley (Kassie et al. 2013; Mekasha et al. 2013). However, the highland stations Butajira and Kulumsa, showed a significant decrease in the annual minimum temperature. A similar result was also reported by Mekasha et al. (2013) for Kulumsa station where it showed a decreasing tendency in daily minimum temperature during a similar study period. Generally, most previous studies reported a warming trends in Ethiopia over the past few decades for both maximum and minimum temperatures (McSweeney et al. 2008; Taye and Zewdu 2012; Tesso et al. 2012; Jury and Funk 2013).

Regarding spatial difference in the rate of warming it can be inferred that the rate of warming was generally higher on the valley floor than in the highland areas. 

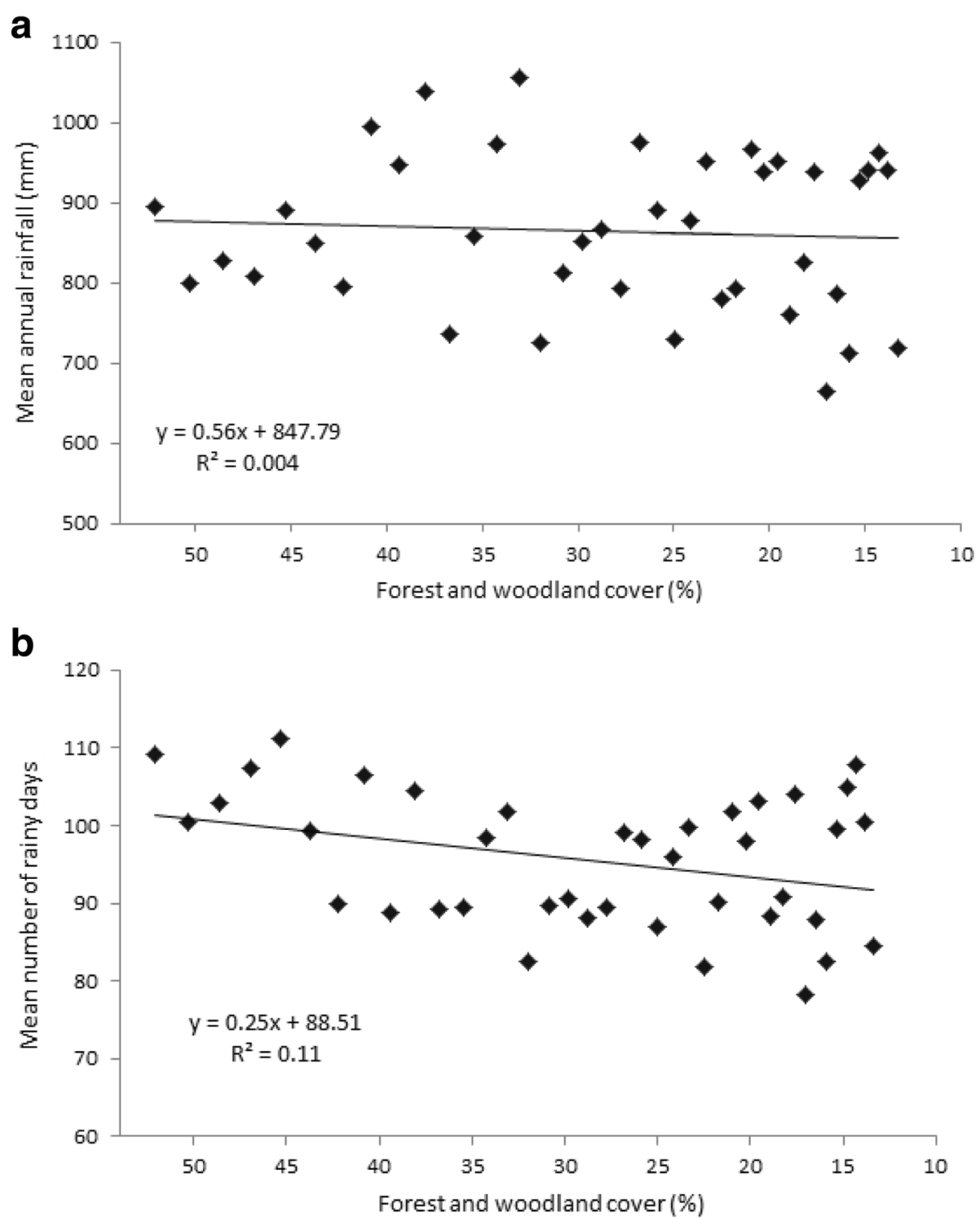

Fig. 5 Simple linear regression between forest and woodland cover and (a) annual rainfall and (b) number of rainy days over 40 years across the Ethiopian Central Rift Valley

This higher rate of warming on the valley floor than in the highland areas could be attributed to persistent deforestation over the past four decades, mostly in the rift valley floor of the area.

\section{Deforestation (Forest and woodland decline)}

From the observed data, the forest and woodland cover steadily decreased from $44 \%$ in 1973 to $14 \%$ in 2006, which increased degraded land by $200 \%$ in the Central Rift Valley (Meshesha et al. 2012). Most of the highly degraded areas due to deforestation are located in the rift valley floor (Fig. 2). Generally, there are strong evidences that indicate an alarming rate of deforestation in the Central Rift Valley. For example; a recent study by Kindu et al. (2013) reported a 56\% natural forest decline between 1973 and 2012 in Munessa-Shashemene area, the major landscape of the Central Rift Valley. A land use land cover dynamics study in the Central Rift Valley by Garedew et al. (2009) documented dramatic trends in deforestation over time, associated with rapid population growth, recurrent drought, rainfall variability and declining crop productivity. Similarly, Dessie and Kleman (2007) also reported conversion of more than $82 \%$ of high forests in the south-central Rift Valley of Ethiopia in about 28 years (1972-2000). 

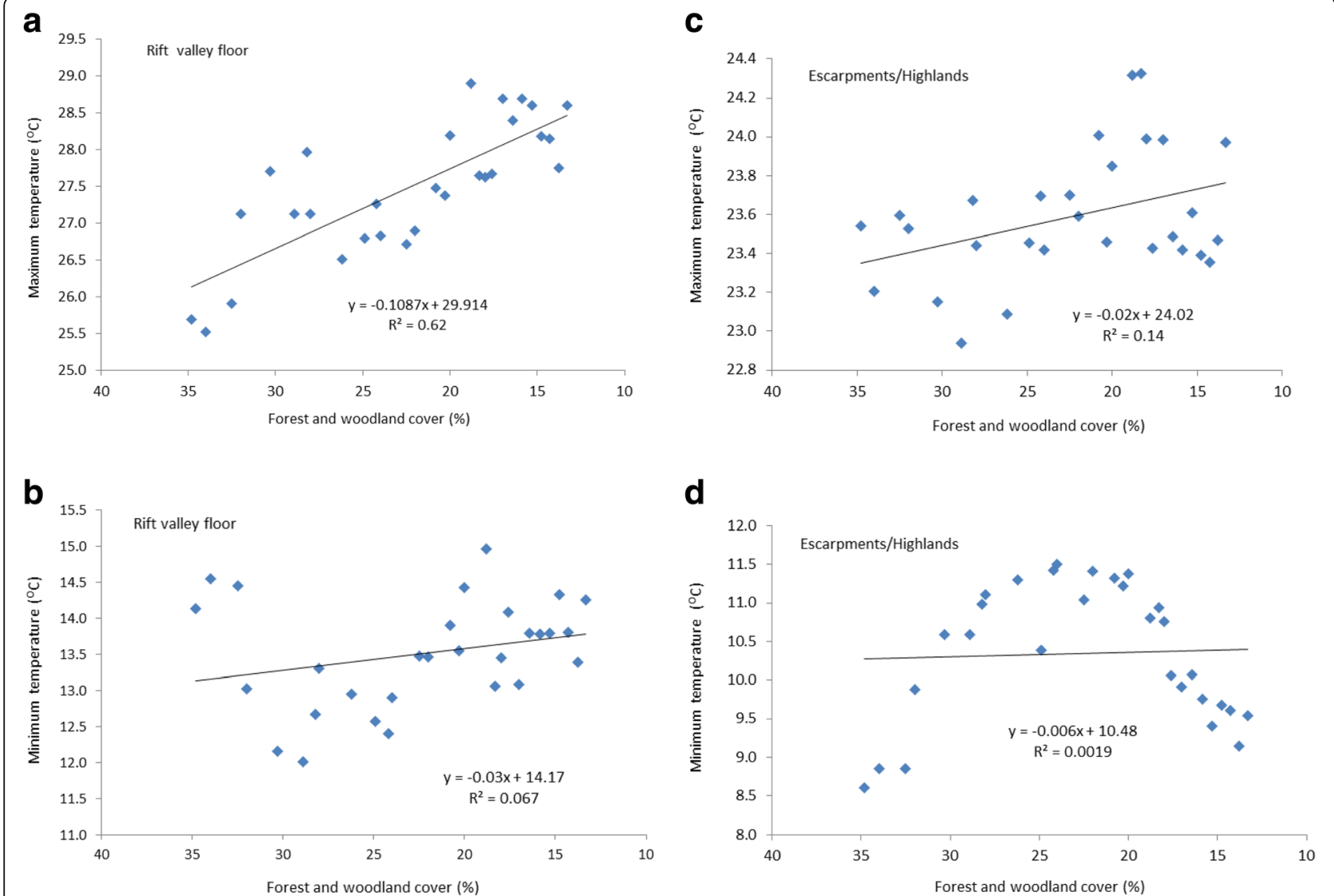

Fig. $\mathbf{6}$ The relationship between forest and woodland cover and $(\mathbf{a}, \mathbf{c})$ maximum temperature and $(\mathbf{b}, \mathbf{d})$ minimum temperature for $(\mathbf{a}, \mathbf{b})$ the rift valley floor and $(\mathbf{c}, \mathbf{d})$ escarpments/highlands using simple linear regression. The lines indicate the linear fitting of the forest and woodland cover and temperature for 1981-2009

\section{Effect of deforestation on long-term rainfall pattern}

Annual rainfall and number of rainy days over the 40 years period increased on the valley floor but the forest and woodland cover continuously decreased. If this change in land cover plays a negative role in rainfall distribution, then rainfall should have decreased on the valley floor as in the escarpments/highlands, because more of the degraded areas are on the valley floor (Fig. 2), and the valley floor has a lower actual annual evapotranspiration $(656 \mathrm{~mm})$ than the escarpments $(892 \mathrm{~mm})$ and highlands (917 $\mathrm{mm}$ ), because it is mostly covered with bare lacustrine soils (Ayenew 2003). The potential evaporation, however, ranges from $>2500 \mathrm{~mm}$ on the valley floor to $<1000 \mathrm{~mm}$ in the highlands (Le Turdu et al. 1999). The

Table 5 Best regression models based on stepwise regression showing the relationships between mean annual rainfall and number of rainy days (1970-2009) as dependent variables and slope and elevation as explanatory variables in the Central Rift Valley

\begin{tabular}{|c|c|c|c|}
\hline \multicolumn{4}{|l|}{ 40-year data (1970-2009) } \\
\hline Dependent variables & Model & $R^{2}$ & $P$ \\
\hline Annual rainfall (mm) & Rainfall $=50.47 \times$ slope +756.16 & 0.29 & $0.03^{*}$ \\
\hline Annual number of rainy days & $\begin{array}{l}\text { Number of rain days }= \\
0.048 \times \text { elevation }+6.60 \times \text { slope }-13\end{array}$ & 0.60 & $\begin{array}{l}\text { Slope }=0.048^{*} \\
\text { Elevation }=0.006^{*}\end{array}$ \\
\hline \multicolumn{4}{|l|}{ Two-year data (2012-2013) } \\
\hline Annual rainfall (mm) & $Y=0.69 \times$ elevation -529.94 & 0.26 & 0.05 \\
\hline Annual number of rainy days & $Y=-1.77 \times$ distance to forest +173.49 & 0.40 & $0.01^{*}$ \\
\hline
\end{tabular}



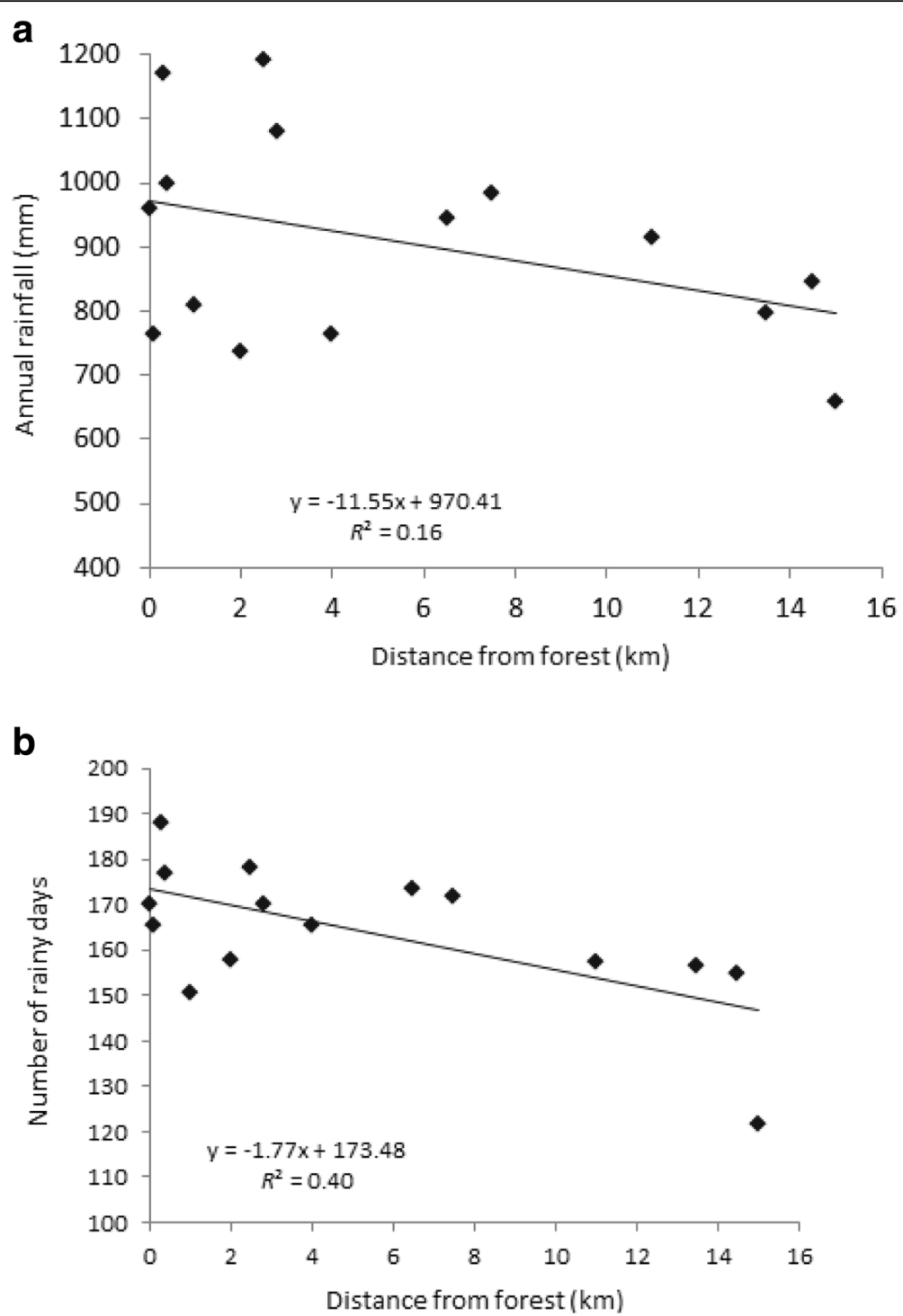

Fig. 7 Simple linear relationships between distance from forest and (a) annual rainfall and (b) number of rainy days for the two-year rainfall data (2012-2013) in the Central Rift Valley

continuous degradation of the vegetation, intensive cultivation, and low actual evapotranspiration pose a question: why is rainfall increasing on the valley floor? Three possible explanations could be offered.

(i) The increasing temperature on the valley floor over the last 40 years has increased evaporation, mainly from the four lakes (Ziway, Langano, Abiyata, and Shala) that occupy roughly $11 \%$ of the total area of the Central Rift Valley (Ayenew 2003), to the extent that the increased evaporation could significantly alter the water cycle and lead to an increase in rainfall. The five stations that recorded increasing rainfalls (Langano, Bulbula, Ziway, Adami Tulu, and Meki) are also close to the lakes (within $7 \mathrm{~km}$, Fig. 1). Existing studies indicated that Mesoscale (1-30 km radius) and local scale (300 $\mathrm{m}$ to
$2 \mathrm{~km}$ radius) climate is influenced by proximity and size of water surfaces (Aguilar et al. 2003). For example, Nieuwolt (1977) reported that Lakes Abaya and Chamo on the valley floor farther south in the rift valley produce large amounts of water vapour and also create local disturbances that are conducive to the production of rain. Similarly, Haile et al. (2009) reported the development of high and thick clouds over Lake Tana in north-western Ethiopia and frequent rains heavier than $10 \mathrm{~mm} / \mathrm{h}$ at stations relatively close to the lake. Lauwaet et al. (2012) found differences in rainfall patterns with distance from Lake Chad, but largescale atmospheric processes were not affected. There is also further evidence elsewhere that showed the construction of small artificial lakes augmented rainfall in semi-arid Mexico (Jauregui 1991). Generally, large inland lakes 
together with highly variable topography and vegetation can cause significant spatial variability in the rainfall pattern in eastern Africa (Nicholson 1998).

(ii) Deforestation in areas close to water bodies such as lakes leads to lake breezes that in turn are favourable for moisture transport and increased rainfall (Mawalagedara and Oglesby 2012).

(iii) The expansion of irrigation in the study area since 1973, particularly around the lakes, could likely have contributed to increased evapotranspiration, which may have contributed to the rainfall increase. Segal et al. (1998) found that irrigation did indeed alter rainfall in a mesoscale model.

In any case, our findings suggest that increasing temperatures and the presence of lakes affect rainfall distribution more strongly than change in vegetative cover on the valley floor. A similar argument was suggested by Meher-Homji (1980) in India, where coastal stations did not record declining rainfall despite high deforestation in the area.

\section{Effect of deforestation on temperature}

A better relationship is observed between forest and woodland cover decline and maximum temperature in the rift valley floor than in the escarpment/highlands, which is consistent with the higher increase in the maximum daily temperature in the rift valley floor than the escarpment/highlands. Generally, there is a consensus on the idea that the day time temperature (maximum temperature) increase is always associated with local deforestation (Casitillo and Gurney 2013, Houspanossian et al. 2013). For example, the most recent study by Gourdij et al. (2015) found a day time temperature increase of $0.4{ }^{\circ} \mathrm{C}$ per decade in areas that have experienced rapid deforestation within $50 \mathrm{~km}$ radius since 1983 a rate which is about three times the global average increase, whereas night time minimum temperature increases $0.18{ }^{\circ} \mathrm{C}$ per decade, a rate consistent with global average temperature increase. Similarly, Lejeune et al. (2017) reported higher values of Tmax over open land compared to forests which indicates a daytime warming impact of deforestation by almost $1.5{ }^{\circ} \mathrm{C}$. Zhang et al. (2014) have also found much higher Tmax increase (by about $2.4{ }^{\circ} \mathrm{C}$ ) in the open land than that of the forested land, while Tmin of the open land was almost identical to that of the forested land. Alkama and Cescatti (2016) and $\mathrm{Li}$ et al. (2015) also found higher daytime temperature over open land than over surrounding forests. Modelling studies of deforestation have similarly predicted that reductions in evaporative cooling associated with the loss of vegetation will increase regional air temperatures (Snyder 2010). Thus, the decrease in transpiration combined with a reduction of surface roughness due to deforestation suppresses the flux of sensible heat from the surface that in turn will increase the surface temperature.

\section{The influence of remnant forests and topographical variables on spatial rainfall distribution Long-term rainfall (1970-2009)}

The significant effect of slope in the spatial rainfall variability in the Central Rift Valley could be attributed to the role of steeper slopes in providing stronger orographic lifting and hence higher rainfall (Buytaert et al. 2006). The relatively less $R^{2}$ value of 0.29 looks less satisfactory predictor, but other historical studies with such low R-squared values reported the regression model as the best predictor variable. For example, Basist et al. (1994) studied statistical relationship between topography and precipitation pattern, in Hawaii, using multiple regression and found that the model with $R^{2}$ value of 0.31 (slope orientation independent variable) as statistically significant and best predictor of the annual precipitation pattern. The same study (Ibid) in Kenya reported the $\mathrm{R}^{2}$ value of 0.39 (elevation independent variable) as the only significant topographic predictor of mean annual precipitation. Similarly, with the $\mathrm{R}^{2}$ value of 0.22 , they found statistically significant bivariate relationship between slopes and mean annual relationship in Norway.

Elevation greatly influences the climate of Ethiopia but explained less of the spatial variability of total annual rainfall in the Central Rift Valley. The pattern of increasing rainfall associated with increasing altitude in the Central Rift Valley is modified at high altitudes by the influence of the high mountains, which may cause either rain shadows or areas of heavy orographic rainfall (Makin et al. 1975). The orographic effect on the spatial distribution of rainfall over the area is substantial. Drier pockets occur in rain shadows. Areas close to the eastern highlands receive more rain annually than areas farther from the mountainous region even if the latter are higher (Makin et al. 1975). For example, Assela (2390 m a.s.l) receives a mean annual rainfall of $1118 \mathrm{~mm}$, but Kulumsa (2200 m a.s.l), just $11 \mathrm{~km}$ to the north, receives only $810 \mathrm{~mm}$, and Sagure (2480 m a.s.l) south of Assela receives only $776 \mathrm{~mm}$. Topographical variables such as slope and aspect and characteristics of the dominant air masses in the highlands of Ethiopia are generally more important than elevation in explaining the variability of annual rainfall (Krauer 1988). The absence of significant correlations between remnant forest (stated as distance from forest) and long-term annual rainfall and number of rainy days may partly be attributable to the non-systematic location of the meteorological stations relative to the remnant forest (Munessa-Shashemene forest). Most of the stations are not near this remnant forest. Furthermore, the meteorological stations in this study are distributed across different climatic zones (semi-arid, subhumid, and humid climates), but the remnant forest mostly 
has a sub-humid climate. Thus, it is worth exploring additional metrics to measure rainfall (and relate it to local forest cover) than a point-average - in part as a sensitivity analysis but also to find out more about possible relationships between the presence of forest and local rainfall. Therefore, further study using spatially averaged rainfall estimates in relation to (equally spatially explicit) land cover characteristics is important.

\section{Short-term rainfall (2012-2013)}

Unlike long term rainfall, in short term rainfall analysis, the annual rainfall was significantly explained by elevation $\left(R^{2}=0.26\right)$. This could be attributed to the consistent difference of elevation amongst meteorological stations. Forests were good predictors of the short-term annual number of rainy days, consistent with the findings of other studies that found better correlations of rainy days with forests than with total rainfall (Meher-Homji 1980, 1991; Wilk et al. 2001). The presence of significant correlations between remnant forest (stated as distance from forest) and short-term number of rainy days may partly be attributable to the systematic location of the meteorological stations relative to the remnant forest (Munessa-Shashemene forest). Our tipping bucket rain gauges were systematically installed along transects of approximately $60 \mathrm{~km}$ traversing both forested and open areas (Fig. 1).

\section{Conclusions}

This study did not find a significant correlation between a long term decline in forest and woodland cover and long-term rainfall in the Central Rift Valley. However, there is a strong relationship between long term forest and woodland cover decline and maximum temperature in the rift valley floor. The remnant forests had a significant effect on the spatial variability of the number of rainy days as observed from short-term (two years) rainfall data. Topographic factors play a significant role than forest cover in explaining the spatial variability of annual rainfall in the long-term and short term time scale in the Central Rift Valley. Slope is the most important factor in explaining long-term rainfall spatial variability while both elevation and slope are the two most important topographic factors in explaining the variability in annual number of rainy days.

Generally, our hypothesis that long term deforestation affects rainfall and temperature pattern and remnant small scale forest has a beneficial effect on rainfall could not be fully confirmed because of the complication of the presence of a chain of lakes in the Central Rift Valley. The analysis of the role of lakes for increasing rainfall in the surrounding area, through moisture transport from the lakes to the nearby land surface (Lake Breeze), was carried out by indirect method and revising existing literature. However, the limits of our dataset prevent any further analysis to draw a robust conclusion about the role of these lakes in affecting the surrounding rainfall pattern. Despite such limitations, this study is an important step toward improving our understanding of the relationship between forests and rainfall variability on smaller spatial scales given Ethiopia's diverse topography and climate.

\section{Acknowledgements}

This study was funded by the Netherlands Organization for International Cooperation in Higher Education (Nuffic). The authors thank the Royal Dutch Embassy in Ethiopia for facilitating the deployment of the rain gauges to Ethiopia. We also acknowledge the primary schools in West Arsi zone in Ethiopia who willingly allowed us to install rain gauges in the school compounds.

\section{Authors' contributions}

AM wrote most of the text and conducted most of the data gathering. AM, $E \vee L$ and $A B$ performed the data analysis. WB, SK and LS helped to draft manuscript. Each co-author provided their invaluable expert insights, opinions and recommendations for the text and wrote certain important paragraphs. All authors read and approved the final manuscript.

\section{Competing interests}

The authors declare that they have no competing interests.

\section{Author details}

${ }^{1}$ Wageningen University, Soil Physics and Land Management Group, Droevendaalsesteeg 4, 6708 Wageningen, PB, Netherlands. ${ }^{2}$ Hawassa University, School of Bio-systems and Environmental Engineering, P.O. Box, 05, Hawassa, Ethiopia. ${ }^{3}$ Hawassa University, Wondo Genet College of Forestry and Natural Resources, P.O. Box, 128 Shashemene, Ethiopia. ${ }^{4}$ Department of Geography \& Environmental Studies, Addis Ababa University, P.O. Box, 150372 Addis Ababa, Ethiopia. ${ }^{5}$ Amsterdam University, P.O. Box, 94248, 1090, GE, Amsterdam, The Netherlands.

Received: 9 April 2017 Accepted: 28 September 2017

Published online: 06 November 2017

\section{References}

Abate A (2004) Biomass and nutrient studies of selected tree species of natural and plantation forests: Implications for a sustainable management of the Munesa- Shashemene forest, Ethiopia. Ph.D. Thesis. University of Bayreuth. pp150

Agnew MD, Palutikof JP (2000) GIS- based construction of baseline climatologies for the Mediterranean using terrain variables. Clim Res 14:115-127

Aguilar E, Auer I, Brunet M, Peterson TC, Wieringa J (2003) Guidelines on climate metadata and homogenization. WCDMP No. 53 - WMO/TD-No. 1186

Alkama R, Cescatti A (2016) Biophysical climate impacts of recent changes in global forest cover. Science 351:600-604

Ayenew T (2003) Evapotranspiration estimation using thematic mapper spectral satellite data in the Ethiopian rift and adjacent highlands. J Hydrol 279:83-93

Ba MB, Nicholson SE (1998) Analysis of convective activity and its relationship to the rainfall over the Rift Valley lakes of East Africa during 1983-1990 using Meteosat Infrared channel. J Appl Meteorol 37:1250-1264

Badger AM, Dirmeyer PA (2016) Remote tropical and subtropical responses to Amazon deforestation. Clim Dyn 46:3057-3066

Bagley JE, Desai AR, Harding KJ, Snyder PK, Foley JA (2014) Drought and deforestation: has land cover change influenced recent precipitation extremes in the Amazon? J Clim 27:345-361

Barry RG (1992) Mountain Weather and Climate. Routledge, London

Basist A, Bell GD, Meentemeyere V (1994) Statistical relationships between topography and precipitation patterns. J Clim 7:1305-1315

Bekele M (2003) Forest Property Rights, the Role of the State, and Institutional Exigency: The Ethiopian Experience. Swedish University of Agricultural Sciences, Department of Rural Development Studies, Uppsala, Sweden, Doctoral thesis 
Bolstad PV, Swift L, Collins F, Regniere J (1998) Measured and predicted air temperatures at basin to regional scales in the southern Appalachian mountains. Agric For Meteorol 91:161-176

Bonan GB (2008) Forests and climate change: Forcing feedbacks and the climate benefits of forests. Science 320:1444-1449

Bright R M et al (2015) Metrics for biogeophysical climate forcings from land use and land cover changes and their inclusion in life cycle assessment: a critical review Environ. Sci.Technol. 49 3291-3303

Buytaert W, Celleri R, Willems P, De B'e B, Wyseure G (2006) Spatial and temporal rainfall variability in mountainous areas: a case study from the south Ecuadorian Andes. J Hydrol 329:413-421

Cao Q, Yu D, Georgescu M, Han Z, Wu J (2015) Impacts of land use and land cover change on regional climate: a case study in the agro-pastoral transitional zone of China. Environ Res Lett 10:124025. https://doi.org/10. 1088/1748-9326/10/12/124025

Castillo CKG, Gurney KR (2013) A sensitivity analysis of surface biophysical, carbon, and climate impacts of tropical deforestation rates in CCSM4CNDV. J Clim 26:805-821

Dallmeyer A, Claussen M (2011) The influence of land cover change in the Asian monsoon region on present-day and mid-Holocene climate. Biogeosciences 8:1499-1519

Daly C, Neilson RP, Phillips DL (1994) A statistical topographic model for mapping climatological precipitation over mountainous terrain. J Appl Meteorol 33:140.158

Davies-Barnard T, Valdes PJ, Singarayer JS, Pacifico FM, Jones CD (2014) Full effects of land use change in the representative concentration pathways Environ. Res Lett 9:114014

de Sherbinin A, Balk D, Yager K, Jaiteh M, Pozzi F, Giri C. and Wannebo, A (2002) "Land-Use and Land-Cover Change," A CIESIN Thematic Guide, Palisades, NY: Center for International Earth Science Information Network of Columbia University. Available on-line at http://sedac.ciesin.columbia.edu/tg/guide_ main.jsp

Dessie G, Kleman J (2007) Pattern and magnitude of deforestation in the South Central Rift Valley Region of Ethiopia. Mt Res Dev 27:162-168

Dirmeyer PA, Shukla J (1994) Albedo as a modulator of climate response to tropical deforestation. Geophys Res:20863-20877

Estoque MA, Gross J, Lai HW (1976) A lake breeze over southern Lake Ontario. Mon Weather Rev 104:386-396

FAO (2010) Global forest resources assessment main report. Food and Agriculture Organization of the United Nations, Rome

Feoli E, Zerihun W (2000) Fuzzy set analysis of the Ethiopian rift valley vegetation in relation to anthropogenic influences. Plant Ecol 1147:219-225

Gadgil S (1978) Lectures on Fundamentals of Climatology. UGC Sp1. Training Programme in Wildlife Biology. Indian Inst. Sci., Bangalore

Garedew E, Sandewall M, Soderberg U, Campbell BM (2009) Land-use and land cover dynamics in the Central Rift Valley of Ethiopia. Environ Manag 44:683694

Gebrehiwot SG, Taye A, Bishop K (2010) Forest Cover and Stream Flow in a Headwater of the Blue Nile: Complementing Observational Data Analysis with Community Perception. Ambio 39:284-294

Gourdij S, Läderach P, Valle AM, Martinez CZ, Lobell DB (2015) Historical climate trends, deforestation, and maize and bean yields in Nicaragua. Agric For Meteorol 200:270-281

Griffiths JF (1972) Climates of Africa. World Survey of Climatology, 10. Elsevier

Haile AT, Rientjes THM, Gieske, ASM (2009) Rainfall Variability over Mountainous and Adjacent Lake Areas: The Case of Lake Tana Basin at the Source of the Blue Nile River. J Appl Meteorol Climatol. 48:1696-1717

Hanif M F, Mustafa M R, Hashim A M, Yusof K W (2016) Deforestation alters rainfall: a myth or reality. Earth and Environmental Science, 37, 012029. oi: https://doi.org/10.1088/1755-1315/37/1/012029

Helsel DR, Frans L (2006) Regional Kendall test for trend. Environ Sci Technol 40 4066-4073

Helsel DR, Hirsch RM (2002) Statistical Methods in Water Resources. US Department of the Interior. http://water.usgs.gov/pubs/twri/twri4a3/

Hession S, Moore N (2011) A spatial regression analysis of the influence of topography on monthly rainfall in East Africa. Int J Climatol 31:1440-1456

Houspanossian J, Nosetto M, Jobbagy EG (2013) Radiation budget changes with dry forest clearing in temperate Argentina. Glob Change Biol 19:1211-1222

Hubbard K (1994) Spatial variability of daily weather variables in the high plains of the USA. Agric For Meteorol 68:29-41
Jauregui E (1991) Effects of Revegetation and New Artificial Water Bodies on the Climate of Northeast Mexico City. Energy and Buildings, 15-16, 447-455

Jury MR, Funk C (2013) Climatic trends over Ethiopia: regional signals and drivers. Int J Climatol 33:1924-1935

Kassie BT, Rötter P, Hengsdijk H, Asseng S, Van Ittersum MK, Kahiluto H, Van Keulen H (2013) Climate variability and change in the Central Rift Valley of Ethiopia: challenges for rainfed crop production. J Agric Sci 152:58-74

Kindu M, Schneider T, Teketay D, Knoke T (2013) Land Use/Land Cover Change Analysis Using Object-Based Classification Approach in Munessa-Shashemene Landscape of the Ethiopian Highlands. Remote Sens 5:2411-2435. https://doi. org/10.3390/rs5052411

Kramer R, Richter D, Pattanayak S, Sharma N (1997) Economic and ecological analysis of watershed protection in eastern Madagascar. J Environ Manag 49: $277-295$

Krauer J (1988) Rainfall, erosivity and isoerodent map of Ethiopia. Soil Conservation Research Project, Research Report 15. University of Berne, Switzerland, p 132

Lauwaet D, van Lipzig NPM, Van Weverberg K, De Ridder K, Goyens C (2012) The precipitation response to the desiccation of Lake Chad. Q J R Meteorol Soc 138:707-719

Lawrence D, Vandecar K (2015) Effects of tropical deforestation on climate and agriculture. Nat Clim Chang 5:27-36

Lawrence PJ, Chase TN (2010) Investigating the climate impacts of global land cover change in the community climate system model. Int J Climatol 30: 2066-2087

Le Turdu C, Coauthors (1999) The Ziway-Shala lake basin system, Main Ethiopian Rift: influence of volcanism, tectonics, and climatic forcing on basin formation and sedimentation. Palaeogeography, Palaeoclimatology and Palaeoecology, 150, 135-177

Lejeune Q, Davin EL, Guillod BP, Seneviratne SI (2015) Influence of Amazonian deforestation on the future evolution of regional surface fluxes, circulation, surface temperature and precipitation. Clim Dyn. 44:2769-2786

Lejeune Q, Sonia IS, Edouard LD (2017) Historical Land-Cover Change Impacts on Climate: Comparative Assessment of LUCID and CMIP5 Multi-model Experiments. J Clim. https://doi.org/10.1175/JCLI-D-16-0213.1.

Li Y, Zhao M, Motesharrei S, Mu Q, Kalnay E, Li S (2015) Local cooling and warming effects of forests based on satellite observations. Nat Commun 6: 6603

Lucia et al (2017) Biophysical effects on temperature and precipitation due to land cover change. Environ Res Lett 12:053002

Makarieva AM, Gorshkov VG, Bai-Lian L (2009) Precipitation on land versus distance from the ocean: evidence for a forest pump of atmospheric moisture. Ecol Complex 6:302-307

Makin MJ, Kingham TJ, Waddams AE, Birchall CR, Teferra T (1975) Development prospects in the southern Rift Valley. Ethiopia. Land Resources Study 21, Land Resources Division, UK Min. Overseas Development, Tolworth, UK

Marquínez J, Lastra J, García P (2003) Estimation models for precipitation in mountainous regions: the use of GIS and multivariate analysis. J Hydrol 270:1-11

Mawalagedara R, Oglesby J (2012) The Climatic Effects of Deforestation in South and Southeast Asia, Deforestation Around the World, Moutinho, P (Ed.), ISBN: 978-953-51-0417-9. INTECH Available from: http://www.intechopen.com/ books/deforestation-around-the-world/the-climatic-effects-ofdeforestation-insouth-and-southeast-asia

McSweeney C, New M, Lizcano G (2008) UNDP Climate Change Country Profiles: Ethiopia, Available at http://www.geog.ox.ac.uk/research/climate/projects/undpcp/index.html?country=Ethiopia\&d1=Reports. Accessed 5 Mar 2017.

Meher-Homji VM (1980) Repercussions of deforestation on precipitation in Western Karnatakum, (and Kerala) India. Archiv fur Meteorologie, Geophysik und Bioklimatologie 28B:385-400

Meher-homji VM (1991) Probable impact of deforestation on hydrological processes. Clim Chang 19:163-173

Mekasha A, Tesfaye K, Duncan AJ (2013) Trends in daily observed temperature and precipitation extremes over three Ethiopian eco-environments. Int J Climatol 34:1990-1999

Meshesha DT, Tsunekawa A, Tsubo M (2012) Continuing land degradation: cause-effect in Ethiopia's central rift valley. Land Degrad Develop 23:130-143. https://doi.org/10.1002/ldr.1061

Mi Z et al (2014) Response of surface air temperature to small-scale land clearing across latitudes Environ. Res. Lett 9:034002

Mohammed MU, Bonnefille R (1991) The recent history of vegetation and climate around Lake Langano. Paleoecology of. Africa 22:275-286 
Moliba Bankanza JC (2013) Spatial Modeling of Summer Precipitation over the Czech Republic Using Physiographic Variables. Geogr Res 52:85-105

Muchane MW (1996) Comparison of the isotope record in Micrite, Lake Turkana, with the historical weather record over the last century. In: Johnson TC, Odada EO (eds) The Limnology, Climatology and Pale climatology of the East African Lakes, Gordon and Breach Publishers, OPA, The Netherlands, pp 431-441

Muluneh A, Bewket W, Keesstra SD, Stroosnijder L (2017) Searching for evidence of changes in extreme rainfall indices in the Central Rift Valley of Ethiopia. Theor Appl Climatol 128:795-809

Musein BS (2006) Remote sensing and GIS for land cover/land use change detection and analysis in the semi-natural ecosystems and agriculture landscapes of the central Ethiopian Rift Valley. Ph.D. Dissertation, Techniche Universität Dresden. Dresden, Germany, p 2006

Nicholson SE (1998) Historical Fluctuations of Lake Victoria and other lakes in the northern rift valley of east Africa. Environmental change and response in east African lakes:7-35

Nieuwolt S (1977) Tropical Climatology: An Introduction to the Climate of Low Latitude. John Wiley \& Sons, Ltd 207 pp

Nobre P, Malagutti M, Urbano DF, de Almeida RA, Giarolla E (2009) Amazon deforestation and climate change in a coupled model simulation. J Clim 22: 5686-5697

Nogherotto R, Coppola E, Giorgi F, Mariotti L (2013) Impact of Congo Basin deforestation on the African monsoon. Atmos Sci Lett 14:45-51

Oettli P, Camberlin P (2005) Influence of topography on monthly rainfall distribution over East Africa. Clim Res 28:199-212

Pattanayak S, Kramer R (2001) Worth of watersheds: a producer surplus approach for valuing drought mitigation in Eastern Indonesia. Environ Dev Econ 6(1): 123-146

Pitman AJ, Lorenz R (2016) Scale dependence of the simulated impact of Amazonian deforestation on regional climate. Environ Res Lett 11:094025. https://doi.org/10.1088/1748-9326/11/9/094025

Ryznar E, Touma JS (1981) Characteristics of true lake breezes along the eastern shore of Lake Michigan. Atmos Environ 15:1201-1205

Sanderson M, Pope E, Santini M, Mercogliano P, Montesarchio M (2012) Influences of EU forests on weather patterns: Final report European Commission (DG Environment)

Savenije HHG (1996) Does moisture feedback affect rainfall significantly? Phys Chem Earth 20:507-513

Segal M, Pan Z, Turner RW, Takle ES (1998) On the potential impact of irrigated areas in North America summer rainfall caused by large-scale systems. J Appl Meteorol 37:325-331

Seifu K (1998) Estimating Land Cover/Land Use Changes in Munessa Forest Area using Remote Sensing Techniques. MSc thesis Report No. 1998: 32, Swedish University of Agricultural Sciences, Skinn skatteberg

Seleshi Y, Zanke U (2004) Recent changes in rainfall and rainy days in Ethiopia. Int J Climatol 24:973-983

Snyder PK (2010) The influence of tropical deforestation on the northern hemisphere climate by atmospheric teleconnections. Earth Interact 14. https://doi.org/10.1175/2010El280.1

Spracklen DV, Garcia-Carreras L (2015) The impact of Amazonian deforestation on Amazon basin rainfall. Geophys Res Lett 42:9546-9552

Taye M, Zewdu F (2012) Spatio-temporal Variability and Trend of Rainfall and Temperature in Western Amhara, Ethiopia: a GIS approach. Glo Adv Res J Geogr Reg Plann 1:65-82

Tesso G, Emana B, Ketema M (2012) A time series analysis of climate variability and its impacts on food production in North Shewa zone in Ethiopia. Afr Crop Sci J 20:261-274

Wilk J, Andersson L, Plermkamon V (2001) Hydrological impacts of forest conversion to agriculture in a large river basin in northeast Thailand. Hydrol Process 15:2729-2748

Woldu Z, Tadesse M (1990) The vegetation in the lakes region of the rift valley of Ethiopia and the possibility of its recoveries. SINET: Ethiopian. Journal of Science 13:97-120

\section{Submit your manuscript to a SpringerOpen ${ }^{\circ}$ journal and benefit from:}

- Convenient online submission

- Rigorous peer review

- Open access: articles freely available online

- High visibility within the field

- Retaining the copyright to your article

Submit your next manuscript at $\boldsymbol{\nabla}$ springeropen.com 